\title{
HUBUNGAN MOTIVASI DENGAN KEMAMPUAN SERVIS BAWAH DALAM PERMAINAN BOLAVOLI
}

\author{
Nova Risma, Rices Jatra \\ novarisma@edu.uir.ac.id, ricesjatra@edu.uir.ac.id \\ Universitas Islam Riau, Fakultas Keguruan dan Ilmu Pendidikan
}

\begin{abstract}
The problem in this study is the lack of activeness and motivation of students of SMP Negeri 6 Pekanbaru in the learning activities of volleyball games, especially in learning service below, so that learning activities do not run optimally. The purpose of this study was to determine the relationship of motivation with the ability to serve under the volleyball game of SMP Negeri 6 Pekanbaru students. This study is correlational that connects the independent variable, motivation $(X)$ with the dependent variable, namely the ability to serve under the game of volleyball ( $Y$ ). The population in this study were all students of SMP Negeri 6 Pekanbaru, totaling 335 people. The sampling technique in this study is Purposive Sampling, so that the students sampled in this study amounted to 54 people. Data collection for motivation is done by distributing questionnaires and service capabilities under Russel-Lange. The data obtained were analyzed using thecorrelation formula product moment with $\alpha=0.05$. Hypothesis test results show there is a relationship between motivation and the ability to service down in the game of volleyball $\left(r_{x y}=0.345>r_{\text {table }} 0.281\right)$ and $\left(t_{\text {arithmetic }}=2.520>t_{\text {table }}=\right.$ 2.012). This means that the higher motivation possessed by SMP Negeri 6 Pekanbaru students, the tendency of lower service ability in volleyball games is also increasing. In another sense, the hypothesis is accepted (significant).
\end{abstract}

Keywords: motivation, services ability the understanding, bolavoli games

\section{ABSTRAK}

Masalah dalam penelitian ini adalah kurangnya motivasi siswa SMP Negeri 6 Pekanbaru pada kegiatan pembelajaran permainan bolavoli, khususya pada pembelajaran servis bawah, sehingga kegiatan pembelajaran tidak berjalan dengan maksimal. Tujuan penelitian ini adalah untuk mengetahui hubungan motivasi dengan kemampuan servis bawah dalam permainan bolavoli siswa SMP Negeri 6 Pekanbaru. Penelitian ini merupakan penelitian korelasional yang menghubungkan antara variabel bebas yaitu motivasi (X) dengan variabel terikat yaitu kemampuan servis bawah dalam permainan bolavoli (Y). Populasi dalam penelitian ini adalah seluruh siswa SMP Negeri 6 Pekanbaru yang berjumlah 335 orang. Teknik pengambilan sampel dalam penelitian ini adalah purposive sampling, sehingga siswa yang dijadikan sampel dalam penelitian ini berjumlah 54 orang. Instrumen penelitian yang digunakan dalam penelitian ini adalah tes kemampuan servis bawah bolavoli untuk mengetahui kemampuan servis bawah dan penyebaran angket untuk mengetahui motivasi siswa. Data yang diperoleh dalam penelitian ini dianalisis dengan analisis korelasi product moment dengan $\alpha=0,05$. Hasil penelitian menunjukkan bahwa terdapat hubungan antara motivasi dengan kemampuan servis bawah dalam permainan bolavoli $\left(r_{x y}=0,345>r_{\text {tabel }} 0,281\right.$ ) dan $\left(t_{\text {hitung }}=2,520>t_{\text {tabel }}=2,012\right)$. Hal ini berarti semakin tinggi motivasi yang dimiliki oleh siswa, maka akan semakin baik kemampuan servis bawahnya dalam permainan bolavoli.

Kata Kunci: motivasi, kemampuan servis bawah, permainan bolavoli

\begin{tabular}{|c|c|c|}
\hline Submitted & Accepted & Published \\
\hline 13 September 2019 & 17 September 2019 & 20 September 2019 \\
\hline
\end{tabular}

\begin{tabular}{|l|l|l|}
\hline Citation & $:$ & Risma, N., \& Jatra, R. (2019). Hubungan Motivasi dengan Kemampuan Servis Bawah dalam Permainan Bolavoli. Jurnal
\end{tabular} PAJAR (Pendidikan dan Pengajaran), 3(5), 1196-1203. DOI: http://dx.doi.org/ 10.33578/pjr.v3i5.7887.

*Copyright (C) 2019 Jurnal PAJAR (Pendidikan dan Pengajaran)

Publish by PGSD FKIP Universitas Riau, Pekanbaru, Indonesia

\section{PENDAHULUAN}

Pendidikan merupakan suatu proses yang dapat dimanfaatkan siswa untuk mengembangkan potensi diri yang dimilikinya. Hal ini sesuai dengan tujuan pendidikan yang telah dirumuskan dalam Undang-undang Nomor 20 Tahun 2003 tentang Sistem Pendidikan Nasional Pasal 1 Butir 1 yang menjelaskan bahwa Pendidikan merupakan usaha sadar dan terencana untuk mewujudkan suasana belajar dan proses pembelajaran agar siswa aktif mengembangkan potensi dirinya untuk memiliki kekuatan spiritual keagamaan, pengendalian diri, kepribadian, kecerdasan, akhlak mulia, dan keterampilan yang diperlukan dirinya, masyarakat, bangsa dan negara. 
Salah satu mata pelajaran wajib yang terdapat di sekolah mulai dari tingkat Sekolah Dasar (SD), Sekolah Menengah Pertama (SMP), dan Sekolah Menengah Atas (SMA) adalah Pendidikan Jasmani Olahraga dan Kesehatan (PJOK). Mata pelajaran PJOK memiliki kontribusi besar untuk pencapaian tujuan pendidikan nasional, hal ini terlihat melalui pendidikan jasmani siswa disosialisasikan ke dalam aktivitas jasmani termasuk keterampilan berolahraga untuk menghasilkan perubahan kualitas individu, baik dalam fisik, mental, serta emosional. Proses pembelajaran Pendidikan Jasmani Olahraga dan Kesehatan (PJOK) berlangsung karena adanya interaksi antara pendidik dan siswa, interaksi ini melibatkan guru sebagai pendidik dan siswa sebagai siswa. Hamalik (2009:33) mengatakan, "Guru yang mempengaruhi berhasil tidaknya proses belajar, dan karenanya guru harus menguasai prinsipprinsip dan metode-metode dalam pembelajaran bolavoli disamping menguasai materi yang akan diajarkan agar tujuan pembelajaran dapat tercapai". Guru sebagai faktor utama yang menentukan keberhasilan pengajaran dituntut kemampuannya untuk dapat menyampaikan bahan ajar kepada siswa dengan baik, untuk itu guru perlu memiliki pengetahuan tentang materi dan cara yang efektif dan efisien dengan kondisi dan karakter siswa yang bermacam-macam, sehingga siswa dapat termotivasi untuk membangun bermacam gagasan-gagasan yang menarik dan membentuk konsepsi sendiri, dan siswa mampu menciptakan kreatifitasnya dalam permainan bolavoli. Sehingga siswa bisa belajar jauh lebih bermakna jika siswa mengalami apa yang dipelajari sehingga siswa memiliki kompetensi yang diharapkan, bukan sekedar mengetahui saja.

Selain melalui PJOK proses pengembangan potensi yang dimiliki oleh siswa juga dapat dilakukan dengan kegiatan ekstrakulikuler disekolah. Menurut Undangundang No 3 Tahun 2005 menjelaskan bahwa "Kegiatan intrakurikuler dan ekstrakurikuler adalah kegiatan yang bertujuan untuk membina dan mengembangkan potensi, kemampuan, minat dan bakat siswa secara menyeluruh". Berdasarkan Undang-Undang di atas dapat disimpulkan bahwa kegiatan intrakulikuler dan ekstrakulikuer memiliki keberartian yang sama dalam proses pengembangan potensi diri siswa.

Bolavoli adalah permainan yang terdiri atas dua regu beranggotakan enam pemain yang diawali dengan memukul bola "servis" untuk dilewatkan di atas net agar mendapatkan angka, namun tiap regu dapat memainkan tiga kali sentuhan untuk mengembalikan bola kepada regu lawan atau tim lawan. Menurut Nuril (2007:19), "Permainan bolavoli merupakan suatu permainan yang komplek yang tidak mudah untuk dilakukan oleh setiap orang, diperlukan pengetahuan tentang teknik-teknik dasar dan teknik-teknik lanjutan untuk dapat bermain bolavoli secara efektif". Teknik-teknik yang terdapat dalam permainan bolavoli tersebut meliputi, teknik passing, servis, spike dan block".

Dalam proses pembelajaran PJOK dan kegiatan ekstrakulikuler, guru dan pelatih seharusnya mampu mengajarkan berbagai keterampilan tekhnik dasar pada suatu cabang olahraga, salah satunya adalah pada materi teknik dasar servis bawah bolavoli. Servis bawah merupakan teknik dasar yang paling penting dalam permainan bolavoli, karena servis bawah merupakan awal untuk memulai permainan. Oleh sebab itu, perlunya siswa menguasai teknik dasar servis bawah dengan baik, sehingga bola dapat melewati net dan bisa menghasilkan poin.

Guru olahraga dianjurkan selalu berusaha menciptakan bentuk teknik dasar servis yang dapat menyulitkan lawan untuk mendapatkan nilai dan siswa merasa nyaman dalam melakukan servis sehingga setiap servis yang dilakukan siswa sudah terotomatisasi dengan kata lain siswa sudah terlatih dengan sendirinya. Dengan demikian servis hendaknya dapat diartikan sebagai satu serangan yang pertama kali bagi regu yang melakukan servis untuk meraih kemenangan. Semakin terlatih siswa dalam melakukan servis maka semakin besar kesempatan tuk mendapatkan poin.

Berdasarkan observasi dan informasi yang peneliti peroleh dari guru PJOK dan pelatih kegiatan ekstrakulikuler bolavoli SMP Negeri 6 Pekanbaru, bahwa masih kurangnya keaktifan dan motivasi siswa pada kegiatan pembelajaran dan pelatihan, khususnya pada pembelajaran servis bawah bolavoli, sehingga kegiatan pembelajaran 
dan pelatihan tidak berjalan dengan maksimal dan tidak sesuai dengan tujuan yang ingin dicapai. Hal ini terlihat, ketika siswa melakukan pembelajaran dan pelatihan servis bawah bolavoli sering kali bola tidak melewati net dan keluar dari lapangan permainan. Seperti halnya, pengenaan bola dengan tangan ketika melakukan servis, posisi berdiri ketika melakukan servis, posisi tubuh ketika melakukan servis yang belum sesuai dengan teknik seharusnya, sedikitnya jumlah tatap muka yang difokuskan terhadap teknik servis bawah yang mengakibat kurang terlatihnya siswa dalam melakukan servis ditambahlagi kurang bervariasi metode-metode pembelajaran yang diberikan kepada siswa pada saat pembelajaran ektrakurikuler yang dilakukan. Selain itu, bola yang di servis juga tidak sesuai dengan sasaran yang telah ditentukan atau ke bagian yang sulit dijangkau pemain lawan. Guru dan pelatih berperan penting sebagai orang yang mengontrol dalam kegiatan pembelajaran dan pelatihan, maka seorang guru dan pelatih perlu menguasai sejumlah metode pembelajaran dan pelatihan sehingga siswa lebih aktif dan kreatif untuk menghindari rasa jenuh siswa dalam menerima materi, maka pada saat yang bersamaan muncullah motivasi mereka dalam menerima setiap materi

\section{KAJIAN TEORETIS}

Teknik cara servis bawah pada permainan bola voli adalah teknik dasar yang paling awal dipelajari dan juga teknik yang banyak diajarkan kepada pemula. Teknik servis ini sangat berguna kala memulai permainan bola voli atau melakukan putaran/babak baru. Biasanya ada area yang ditentukan untuk melakukan servis yang merupakan area wajib. Berikut ini adalah tata cara melakukan servis bawah yakni:

1. Pertama tentunya berdiri di area yang memang digunakan untuk servis.

2. Mengambil sikap awal yakni dengan memajukan kaki kiri, lebih maju dibandingkan dengan kaki kanan. servis bawah yang diberikan. Dapat dikatakan, apabila guru dan pelatih dapat memberikan motivasi dan meyakinkan siswa dalam melakukan servis dengan menyajikan berbagai pola atau metode sehingga siswa memiliki ketertarikan dalam melakukan dan menjalankan materi yang telah diberikan oleh pelatih ataupun guru maka secara tidak langsung metode tersebut sudah mampu mempengaruhi motivasi siswa dalam melakukan servis bawah dalam permainan bolavoli, maka guru dan pelatih tidak akan terlalu sulit untuk mengatasi masalah yang dihadapi oleh siswa.

Motivasi belajar siswa dalam pembelajaran servis bawah bolavoli adalah suatu perubahan energi dalam pribadi siswa yang ditandai dengan timbulnya efektif dan reaksi untuk mencapai tujuan, tujuan tersebut akan membangkitkan semangat dan memotivasi belajar siswa dalam materi servis bawah bolavoli. Pemberian motivasi merupakan salah satu cara untuk menumbuhkan minat siswa pada saat kegiatan pembelajaran dan pelatihan, sehingga siswa menjadi aktif dalam mengikuti kegiatan pembelajaran PJOK dan pelatihan bolavoli pada kegiatan ekstra kulikuler.

3. Bola voli kemudian dipegang pada tangan kiri yang diarahkan ke dapan.

4. Tangan kanan mengepal dan kemudian diayunkan dari arah belakang.

5. Bola voli yang ada di tangan kiri dilambungkan ke atas dan kemudian tangan kanan diayunkan ke depan hingga memukul tepat pada bagian bawah bola.

6. Bola dipukul keras hingga melewati net ke daerah lawan, namun tidak sampai keluar garis karena akan dianggap gagal. 


\section{METODE PENELITIAN}

Penelitian ini merupakan penelitian kuantitatif dengan metode penelitian korelasional yang bertujuan untuk melihat hubungan variabel bebas dengan variabel terikat. Adapun variabel bebas (X) dalam penelitian ini adalah motivasi dan variabel terikatnya $(\mathrm{Y})$ adalah kemampuan servis bawah dalam permainan.

Penelitian ini dilaksanakan di SMP Negeri 6 Pekanbaru, pada bulan Desember 2017 sampai dengan bulan Januari 2018. Populasi dalam penelitian ini adalah seluruh siswa SMP Negeri 6 Pekanbaru yang berjumlah 335 orang. Tekhnik penarikan sampel dalam penelitian ini menggunakan tekhnik penarikan sampel purposive sampling. Sugiyono (2011:85) berpendapat bahwa purposive sampling adalah teknik penentuan sampel dengan pertimbangan tertentu. Berdasarkan pertimbangan yang telah dilakukan, maka yang dijadikan sampel dalam penelitian ini adalah siswa yang mengikuti ekstra kulikuler olahraga bolavoli yang berjumlah 54 orang.

\section{HASIL DAN PEMBAHASAN Hasil Penelitian}

Berdasarkan Hasil penelitian yang telah dilakukan maka data diperoleh pada penelitian ini akan didskripsikan menurut kelompok data sebagai berikut:

Data Tes Motivasi Siswa SMP Negeri 6 Pekanbaru
Teknik pengumpulan data dalam penelitian ini dilakukan dengan dua cara yaitu penyebaran angket sdebagai instrumen motivasi dan tes kemampuan servis bawah untuk mengetahui kemampuan servis bawah bola voli yang dimiliki oleh sampel penelitian. Sebelum penyebaran angket dilakukan kepada sampel penelitian, terlebih dahulu angket tersebut diujicobakan pada sampel yang tidak terpilih dengan tujuan untuk menguji validitas dan realibilitas angket penelitian.

Analisis data yang digunakan untuk menganalisis data penelitian ini adalah analisis korelasi Product Moment dari Pearson dengan $\alpha=0,05$. Hal ini bertujuan untuk melihat hubungan motivasi dengan kemampuan servis bawah permainan bolavoli siswa SMP Negeri 6 Pekanbaru. Adapun formula yang digunakan dalam penelitian ini adalah sebagai berikut:

$$
r x y=\frac{n \sum X Y-\left(\sum X\right)\left(\sum Y\right)}{\sqrt{\left\{n \sum X^{2}-\left(\sum X\right)^{2}\right\}\left\{n \sum Y^{2}-\left(\sum Y\right)^{2}\right\}}}
$$

Dari hasil tes motivasi yang telah dilakukan pada 35 orang sampel penelitian dan dikelompok kan menurut kelas interval masingmasing maka diperoleh data penelitian sebagai berikut:

Tabel 1. Distribusi Frekuensi Data Tes Motivasi Siswa SMP Negeri 6 Pekanbaru

\begin{tabular}{cccc}
\hline Kelas Interval & Kategori & fa & Fr\% \\
\hline$\geq 126$ & Sangat Tinggi (ST) & 5 & $14,29 \%$ \\
$102-125$ & Tinggi (T) & 9 & $25,71 \%$ \\
$78-101$ & Sedang (S) & 15 & $42,86 \%$ \\
$54-77$ & Rendah (R) & 6 & $17,14 \%$ \\
$\leq 53$ & Sangat Rendah (SR) & 0 & $0,00 \%$ \\
& Jumlah & $\mathbf{3 5}$ & $\mathbf{1 0 0 \%}$ \\
\hline
\end{tabular}

Berdasarkan tabel di atas dapat dilihat bahwa jumlah skor siswa yang berada pada kelas interval $\geq 126$ dengan kategori motivasi sangat tinggi adalah sebanyak 5 orang $(14,29 \%)$, jumlah skor siswa yang berada pada kelas interval 102125 dengan kategori tinggi sebanyak 9 orang $(25,71 \%)$, jumlah skor siswa yang berada pada kelas interval 78-101 dengan kategori sedang 
sebanyak 15 orang $(42,86 \%)$, jumlah skor siswa yang berada pada kelas interval 54-77 dengan kategori rendah sebanyak 6 orang $(17,14 \%)$, dan jumlah skor siswa yang berada pada kelas interval $\leq 53$ dengan kategori sangat rendah sebanyak 0 orang $(0,00 \%)$. Untuk lebih jelasnya histogram data tes motivasi siswa SMP Negeri 6 Pekanbaru dapat diihat pada gambar di bawah ini.

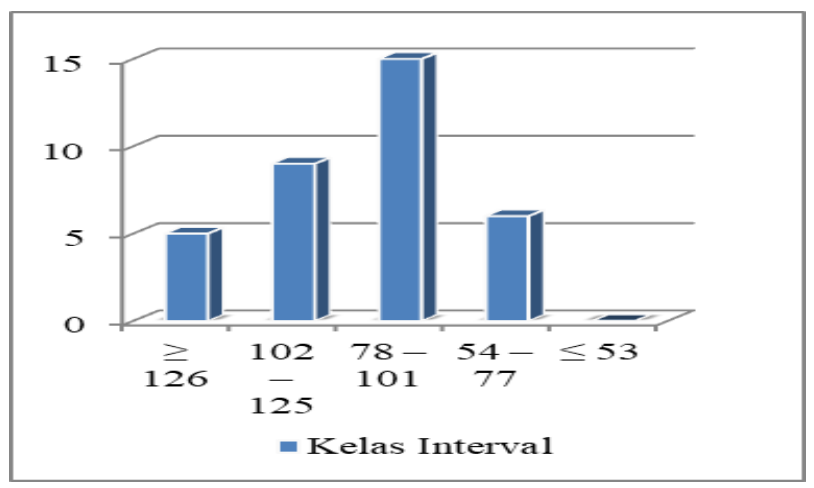

Gambar 1. Histogram Data Tes Motivasi Siswa SMP Negeri 6 Pekanbaru

Data Tes Ketempilan Servis Bawah Bolavoli Siswa SMP Negeri 6 Pekanbaru

Dari hasil tes keterampilan servis bawah bolavoli yang telah dilakukan pada 35 orang sampel penelitian dan dikelompok kan menurut kelas interval masing-masing maka diperoleh data penelitian sebagai berikut:

Tabel 1. Distribusi Frekuensi Data Tes Keterampilan Servis Bawah Bolavoli Siswa SMP Negeri 6

\begin{tabular}{ccc}
\multicolumn{3}{c}{ Pekanbaru } \\
\hline Kelas Interval & Fr & fr\% \\
\hline$>19,21$ & 4 & $11,43 \%$ \\
\hline $12,01-19,20$ & 11 & $31,43 \%$ \\
\hline $7,21-12,00$ & 13 & $37,14 \%$ \\
\hline $4,81-7,20$ & 7 & $20,00 \%$ \\
\hline$<4,81$ & 0 & $0,00 \%$ \\
\hline Jumlah & $\mathbf{3 5}$ & $\mathbf{1 0 0 \%}$ \\
\hline
\end{tabular}

Berdasarkan tabel di atas, dapat dilihat bahwa jumlah skor siswa yang berada pada kelas interval >19,21 sebanyak 4 orang $(11,43)$, jumlah skor siswa yang berada pada kelas interval 12,0119,20 sebanyak 11 orang, jumlah skor siswa yang berada pada kelas interval 7,21-12,00 sebanyak 13 orang $(37,14 \%)$, jumlah skor siswa yang berada pada kelas interval 4,81-7,20 sebanyak 7 orang $(20,00 \%)$ dan jumlah skor siswa yang berada pada kelas interval $<4,81$ sebanyak 0 orang $(0,00 \%)$. Untuk lebih jelasnya histogram data tes kemampuan servis bawah bolavoli siswa SMP Negeri 6 Pekanbaru dapat dilihat pada gambar di bawah ini. 


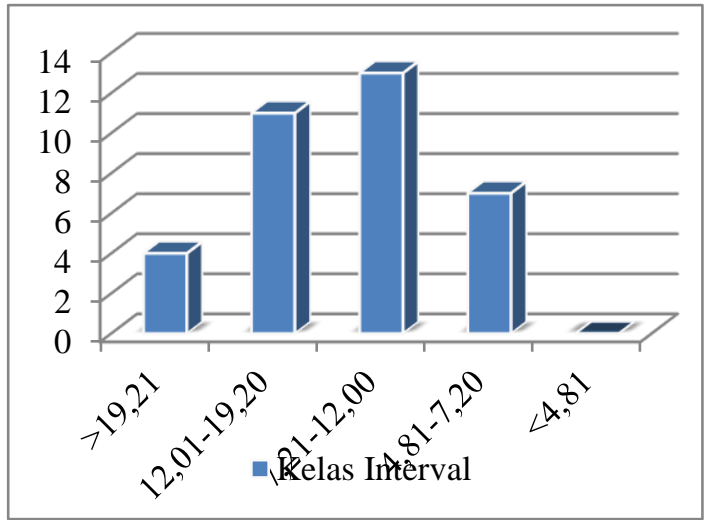

\section{Gambar 2. Histogram Data Tes Kemampuan Servis Bawah Bolavoli Siswa SMP Negeri 6 Pekanbaru}

\section{Hasil Analisis Data Penelitian}

Dari data yang diperoleh dalam penelitian ini selanjutnya dianalisis dengan analisis korelasi product moment dengan $\alpha=0,05$. Hasil analisis data penelitian ini menunjukkan, bahwa $\mathrm{r}_{\text {hitung }}=$ $0,345>r_{\text {tabel }}=0,281$. Selanjutnya, besar hubungan antara motivasi dengan kemampuan servis bawah dalam permainan bolavoli siswa SMP Negeri 6 Pekanbaru adalah $=2,520$. Dapat disimpulkan, bahwa $\mathrm{r}_{\text {hitung }}=0,345>\mathrm{r}_{\text {tabel }}=0,281$ dan $\mathrm{t}_{\text {hitung }}=$ $2,520>\mathrm{t}_{\text {tabel }}=2,012$, maka Ho ditolak dan Ha diterima. Artinya, terdapat hubungan yang signifikan antara motivasi dengan kemampuan servis bawah dalam permainan bolavoli siswa SMP Negeri 6 Pekanbaru. Untuk lebih jelasnya hasil analisis data yang diperoleh dalam penelitian ini dapat dilihat pada tabel berikut:

Tabel 3. Rangkuman Hasil Analisis Data Penelitian

\begin{tabular}{cccccc}
\hline Variabel & $\mathbf{r}_{\mathbf{x y}}$ & $\mathbf{r}_{\text {tabel }}$ & $\mathbf{t}_{\text {hitung }}$ & $\mathbf{t}_{\text {tabel }}$ & Keterangan \\
\hline $\begin{array}{c}\text { Motivasi }(\mathrm{X}) \\
\text { Kemampuan }\end{array}$ & 0,345 & 0,281 & 2,520 & 2,012 & Signifikan \\
$\begin{array}{c}\text { Servis Bawah } \\
\text { Bolavoli (Y) }\end{array}$ & & & & & \\
\hline
\end{tabular}

\section{Pembahasan}

Berdasarkan temuan atau hasil analisis data, ternyata tingkat motivasi yang dimiliki siswa SMP Negeri 6 Pekanbaru mempunyai hubungan secara signifikan terhadap kemampuan servis bawah dalam permainan bolavoli. Siswa yang memiliki motivasi yang tinggi dalam berlatih bolavoli, maka siswa tersebut akan mempelajari dengan penuh rasa semangat untuk meningkatkan kemampuan teknik dasar dalam permainan bolavoli, khususnya pada servis bawah.

Purwato (2007:61) mengemukakan bahwa motivasi merupakan suatu pernyataan yang kompleks dalam suatu organisme yang mengarahkan tingkah laku terhadap suatu tujuan.
Selanjutnya Mc. Donald dalam Sardiman (2001:71), "motivasi adalah perubahan energi yang ditandai dengan munculnya "feeling" dan didahului dengan tanggapan terhadap adanya tujuan". Berikut ini adalah penjabarannya : 1) motivasi itu mengawali terjadinya perubahan energi pada diri setiap individu manusia. Perkembangan motivasi akan membawa beberapa perubahan energi di dalam sistem "neurophysiological" yang ada pada organisme manusia. Karena menyangkut perubahan energi manusia, penampakannya akan menyangkut kegiatan fisik manusia, 2) motivasi ditandai dengan munculnya rasa "feeling", afeksi seseorang. Dalam hal ini motivasi relevan dengan 
persoalan-persoalan kejiwaan, afeksi dan emosi yang dapat menentukan tingkah laku manusia. Motivasi akan dirancang karena adanya tujuan, jadi motivasi dalam hal ini sebenarnya merupakan respon dari suatu aksi yakni tujuan.

Berdasarkan uraian yang telah dikemukakan di atas, maka dapat disimpulkan bahwa motivasi merupakan sebuah dorongan dari dalam diri seseorang yang menghasilkan sebuah energi untuk mewujudakan sebuah tujuan. Motivasi memang muncul dari dalam diri manusia, tetapi kemunculannya karena $t$ erangsang/terdorong oleh adanya unsur lain, dalam hal ini adalah tujuan, tujuan yang dimaksud adalah menyangkut soal kebutuhan.

Seorang pemain atau atlet dalam suatu cabang olahraga diharapkan untuk memiliki motivasi untuk berprestasi. Komarudin (2014:25) menyatakan bahwa motivasi berprestasi merupakan suatu dorongan, hasrat dan pendorong untuk dapat unggul dan mengungguli prestasi yang telah diraih diri sendiri atau orang lain. Seorang pelatih atau guru harus bisa membangkitkan motivasi yang dimiliki oleh seorang atlet atau siswa.

Pada dasarnya se. rvis dalam sebuah permainan bolavoli merupakan pukulan pembukaan untuk memulai suatu permainan. Namun demikian sesuai dengan kemajuan permainan, servis dijadikan suatu awalan untuk melakukan serangan dalam sebuah permainan. Hal ini sesuai pendapat Subroto (2014:61) menyatakan bahwa servis merupakan awalan terjadinya suatu permainan bolavoli, akan tetapi sesuai dengan perkembangan zaman servis menjadi awalan pertama yang penting dalam membangun sebuah serangan. Seiring dengan itu Roesdiyanto dalam Novi, dkk (2014) pada Jurnal Olahraga Pendidikan Vol. 1 (1) menyatakan bahwa, "Servis dalam permainan bolavoli adalah sarana pertama untuk mengadakan serangan terhadap regu lawan, dengan memiliki servis yang baik akan membuat suatu regu bermain dengan sangat efisien, tetapi akan menghasilkan kemenangan yang besar".

Berdasarkan pendapat di atas, dapat disimpulkan bahwa servis merupakan bagian terpenting dalam sebuah permainan bolavoli, hal ini dikarenakan oleh servis merupakan suatu serangan pertama yang dapat dilakukan oleh tim untuk mencetak poin. Maka dari itu, seorang pemain bolavoli dituntut untuk memiliki kemampuan servis bolavoli yang baik agar dapat memanfaatkan peluang pertama untuk menghasilkan poin bagi tim dalam sebuah serangan.

Apabila seorang pemain bolavoli memiliki sebuah servis yang baik, maka timnya mendapat kesempatan pertama untuk mengendalikan jalannya sebuah pertandingan. Salah satu tekhnik dasar dalam melakukan servis dalam permainan bolavoli adala servis bawah. Servis bawah merupakan bagian terpenting yang harus dikuasai oleh pemain bolavoli pemula. Servis bawah yaitu servis yang dilakukan dari bawah dengan menggunakan lengan. Nuril (2007:20), "Posisi awal untuk melakukan servis tangan bawah adalah berdiri dengan posisi melangkah dengan kaki depan berlawanan dengan tangan yang akan memukul bola”.

Berdasarkan uraian di atas dapat disimpulkan bahwa seorang pemain bolavoli pemula dituntut untuk memiliki kemampuan servis bawah tersebut, maka perlu sebuah pelatihan servis bawah bolavoli bagi siswa SMP Negeri 6 Pekanbaru, agar sisiwa dapat melakukan sebuah pelatihan dengan baik dan latihan tersebut dapat mencapai sasaran yang diinginkan. Dalam usaha untuk meningkatkan minat siswa dalam sebuah pelatihan bolavoli khususnya kemampuan servis bawah, maka diperlukan motivasi yang tinggi dari siswa tersebut. Seorang pelatih ataupun guru diharapkan dapat menjadi pemicu untuk meningkatkan motivasi.

Untuk menguasai teknik dasar servis bawah, sehingga bisa menampilkan permainan secara maksimal dan meraih kemengan. Salah satu cara untuk meningkatkan kemampuan tersebut adalah adanya motivasi dari siswa itu sendiri. Majid (2013:310) menyatakan bahwa, ada tiga sumber yang dapat menjadikan siswa termotivasi dalam belajar, yaitu, "1) lingkungan di rumah, yang membentuk perilaku dalam belajar semenjak usia belia, 2) cara siswa memandang diri mereka sendiri, kepercayaan diri, dan harga diri maupun martabat, 3) sifat diri siswa yang bersangkutan, tingkat kesabaran, dan komitmen."

Berdasarkan uraian di atas, maka dapat disimpulkan bahwa hasil dari sebuah pembelajaran 
atau pelatihan akan menjadi optimal apabila adanya motivasi. Semakin besar motivasi yang dimiliki siswa, maka akan semakin berhasil pula suatu pembelajaran atau pelatihan. Dengan demikian diperlukan seorang guru atau pelatih

\section{SIMPULAN DAN REKOMENDASI}

Berdasarkan hasil temuan penelitian dan pembahasan yang telah diuraikan pada bagian terdahulu, maka pada bab ini dapat disimpulkan, bahwa terdapatnya hubungan yang signifikan motivasi dengan kemampuan servis bawah dalam permainan bolavoli pada siswa SMP Negeri 6 Pekanbaru dengan $r_{\text {hitung }}=0,345>r_{\text {tabel }}=0,281$ dan $\mathrm{t}_{\text {hitung }}=2,520>\mathrm{t}_{\text {tabel }}=2,012$.

Berdasarkan kesimpulan penelitian penulis memberikan rekomendasi sebagai berikut; 1) Diharapkan kepada siswa SMP Negeri 6 Pekanbaru agar meningkatkan kemampuan

\section{DAFTAR PUSTAKA}

Hamalik, O. (2009). Kurikulum dan Pembelajaran. Jakarta: Bumi Aksara.

Komarudin. (2014). Psikologi Olahraga. Bandung: PT Remaja Rosda Karya

Majid, A. (2013). Strategi Pembelajaran. Bandung : Remaja Rosdakarya.

Novi, D dkk. (2014). Pengembangan Pembelajaran Teknik Dasar Servis Bawah Bolavoli untuk Siswa Kelas VIII SMP Negeri 5 Malang. Jurnal Olahraga Pendidikan, 1(1), 81-87.

Nuril, A. (2007). Panduan Olahraga Bolavoli. Surakarta: Era Pustaka Utama.

Purwato, M. N (2007). Psikologi Pendidikan. Bandung: Remaja Rosdakarya. sebagai fasilitator dalam proses pembelajaran atau pelatihan, sehingga kemampuan teknik dasar servis bawah dalam permainan bolavoli siswa SMP Negeri 6 Pekanbaru menjadi lebih baik.

pembelajaran permainan bolavoli pada teknik dasar servis bawah dengan cara menimbulkan kesadaran akan pentingnya pembelajaran PJOK dan kegiatan ekstrakulikuler di sekola sebagai sarana untuk berprestasi. 2) Diharapkan bagi guru PJOK dan pelatih bolavoli untuk bisa menjadi fasilitator yang baik pada proses pembelajaran atau pelatihan, sehingga dapat meningkatlan motivasi siswa dalam pembelajaran PJOK dan kegiatan ekstrakulikuler khususnya pada permainan bolavoli.

Subroto, T \& Yudiana, Y. (2014) Permainan Bolavoli. Bandung: FPOK UPI.

Sugiyono. (2011). Metode Penelitian Kuantitatif, Kualitatif dan $R$ \& $D$. Bandung: CV Alfabeta.

Suherman, E, dkk. (2001). Strategi Pembelajaran Matematika Komtemporer. Bandung : Jica.

Undang- Undang RI No. 20 Tahun 2003 tentang Sistem Pendidikan Nasional. Jakarta: Permendiknas.

Undang- Undang RI No. 3 Tahun 2005 tentang Sistem Keolahragaan Nasional. Jakarta: Citra Umbara. 